\title{
IMPACT OF PRESIDENT BUHARI-LED GOVERNMENT ANTI- CORRUPTION CRUSADE ON ECONOMIC GROWTH AND DEVELOPMENT
}

\author{
Dr. EMMANUEL, TILE AIME ${ }^{1}$, AHMED, ALIYU TANKO ${ }^{2} \&$ Dr. ALIYU HASSAN \\ ISIAKA $^{3}$ \\ ${ }^{1}$ Department of Business Management, \\ College of Advanced \& Professional Studies, Makurdi, Benue State - Nigeria. \\ ${ }^{2}$ Department of Business Administration \& Management, \\ Federal Polytechnic, Nasarawa, Nasarawa State - Nigeria. \\ ${ }^{3}$ Department of Humanities and Social Science, \\ Federal Polytechnic, Nasarawa, Nasarawa State - Nigeria.
}

https://doi.org/10.37602/IJSSMR.2020.3401

\begin{abstract}
The study assessed the impact of President Buhari administration as it tries to curb the menace of corruption in the country. The scourge over the years have been the problem of African essentially Nigeria. Most of the past leaders demonstrated high genuine commitment toward fighting corruption to minimize it. Yet it appears any effort made rather resuscitate or rejuvenate in a greater dimension. The study's specific objective is to determine the impact of Buhari's anti-corruption crusade on the nation's economic growth and development. The data sourced for this work was through a questionnaire. It was analysed through simple percentages. The finding reveals that as President Buhari integrated, implemented and also established institutions like ICPC, EFCC, TSA, Integrated Personnel and Payroll Information System (IPPIS) and whistleblower policy reduced the spate at a minimal level. It concluded that those found guilty of corruption charges against them, irrespective of their affiliation with the President in one way or the other, should be made to face the full wrath of the law to serve as a deterrent to others. The paper recommended there should narrow the economic gap between civil servants, public servants and political office holders in the country. This can relatively reduce the rate of corruption in the country.
\end{abstract}

Keywords: Civil servant, Corruption, Economic growth and IPPIS.

\subsection{INTRODUCTION}

Corruption is the worst enemy confronting nations around the world especially the third world or developing nations. Akpan and Eyo (2018) emphasised that "corruption is as old as human existence on planet earth". Corruption connotes dishonesty or fraudulent behaviour exhibited by people in authority by giving or accepting bribe, favouritism, nepotism, bulk passing or the process by which a word is changed from its original state to one regarded as erroneous or debased. The further classified corruption into: "supportive corruption; 


\section{International Journal of Social Sciences and Management Review}

transactional corruption; extortive corruption; traditional and modern corruption; local, national and international corruption; or representational corruption and grand and petty corruption".

Irrespective of the categories, corruption is an impediment to growth and national development. Adegoke (2017) states that "corruption by Nigerian leaders has caused the country severe losses economically, politically and socially, and these facts are responsible for decayed infrastructure, the downturn of indicators of national development". Also, Folarin (2009) opined that "corruption has become so deep-seated that it has stunted growth in all sectors and has been the primary cause for Nigeria's socio-economic backwardness". Nigeria made a top-ten position in the world ranking of most corruption nations by the Transparency International Perception ranking index 2000 (Folarin 2009). Corruption is responsible for the collapse of teaming public corporations partially or completely such as Nigerian Post Office, Nigerian Railway Corporation, Nigeria's National Air Carrier, Ajaokuta Steel Company, Nigeria Textile Company, Nigeria National Petroleum Corporation, National Electricity and Power Authority, amongst others.

Since the return to democracy in 1999, Nigerian leaders have constantly looked for ways to overcome this monster: corruption. Series of policies were made over the cause of time and institutions were also established to curb the menace. Okpala and Enwefa (2017) argued that in responding to the growing social disorder "various local and international organisations demanded the establishment of institutional agencies to fight corruption". This led to the establishment of Independent Corrupt Practices and Other Related Offences Commission (ICPC) in 2000 and the eventual establishment of the Economic and Financial Crimes Commission (EFCC) in 2003. The agencies swiftly moved into action and uncover a number of cases, many of which were arraigned and convicted while stolen wealth recovered. Mutiullah and Adekunle (2017) advised that "combating corruption in public (and private) service requires strong collective efforts from different sectors in society acting in coordinated ways" otherwise these institutions remain obsolete and dysfunctional.

In the campaigns of President Muhammadu Buhari in 2003, 2007, 2011 and eventual emergency as the President of Nigeria in 2015 and 2019, President Buhari's political manifesto centred on fighting and eliminating corruption from the public life of Nigeria. This cannot be achieved except there is the political will which in Ugoani's opinion is "the demonstration of genuine aspiration of political leaders and significant stakeholders to check perceived causes or effects of corruption at a systematic level in society" (Ugoani 2016:72).

Soon after President Muhammadu Buhari's inauguration on the 29th May 2015, he "assured the wider international community" of his "readiness to cooperate and help to combat financial crime and other challenges of the 21st century" (Inaugural Speech of President Buahri, 2015 paragraph 9). The four-paged speech was solely concerned with fighting corruption and restoring the integrity of the nation before her citizens, Africa and the world. President Buhari, knowing very well the threat of corruption to growth and economic development warned during 2016 Independent Day Celebration that "corruption will kill us if we did not kill corruption" (Vanguard 2016 cited by Makinde 2018). At every given opportunity President Buhari, identifies corruption as the major cause of underdevelopment and socio-economic growth of the country, both in the Nigerian Public sector and Private sector. Corruption is cancer that has eaten deeply into the fabric of Nigeria polity. The 


\section{International Journal of Social Sciences and Management Review}

general global perception about graft in Nigeria is that it is generally acknowledged that corrupt practices are endemic and systemic in both public and private sectors of Nigeria (Makinde 2018).

The President removed fuel subsidy in 2016 and decentralise the importation of petroleum, gas and diesel where independent or private corporations were allowed to source for the fund and import these products thereby taking the burden off government shoulders. The government under President Buhari, also ensured the full implementation of Treasury Single Account (TSA) for federal government revenues; Integrated Personnel and Payroll Information System ((IPPIS) to tackle ghost workers on federal government payroll); Bank Verification Number (BVN) to link multiple accounts to one single identifiable code)); utilisation of Whistleblowers act. The government arrested corrupt past government officials such as Col. Sambo Dasuki, Chief Olisah Metuh, Air vice Marshal Alex Badeh, former CJN Mr Walter Onnoghen, and so on. The Buhari led government also secured the conviction of Senator Joshua Dariye and Mr Jolly Nyame; former governors of Plateau and Taraba States respectively. The anti-corruption crusade has been sweeping in the private and public sectors where online fraudsters popularly called "yahoo boys" are arrested in their numbers on a weekly basis.

\subsection{STATEMENT OF THE PROBLEM}

The governments in power have tried to curb the issue of corruption, the menace still remains in the system. The regime of President Muhammadu Buhari came with the cardinal objective to fight corruption. The government boast of numerous recoveries made from various corruption cases and blockage of government leakages. Yet, there have been allegations of corruption levelled against the people in Buhari's government. Like former Secretary to the Government of Federation, Mr. Babachir Lawal. This followed another allegation of mismanagement and or upright diversion of public funds by Ministers of Transport; and Power/Housing. The Attorney General and Minister of Justice was caught in another scandal of bringing back into public service a labelled pension thief.

In view of the foregoing, therefore, the researcher through investigation discovered that most of the reviewed works did not as a matter of fact did not discussed improved ways by which corruptions can be completely eliminated. Most of the works reviewed did not explain whether the Buhari anti-corruption crusade created significance impact on economic growth and development or not. Moreover, the literature on the subject is scarce; none of the reviewed works is empirically stated. It is in line with the above that the researcher wishes to till the knowledge gap.

\subsection{Objectives of the Study}

I. To determine the impact of the anti-corruption crusade on the nation's economic growth and development.

II. To identify basic challenges of President Buhari-led anti-corruption crusade

\subsection{Research Questions}




\section{International Journal of Social Sciences and Management Review}

I. Does the fight against corruption create a significant impact on economic growth and development of Nigeria?

II. What are the challenges faced by President Buhari-led administrating in curbing corruption?

\subsection{Hypothesis}

Ho1 The Buhari-led anti-corruption crusade do not attract economic growth and development.

Ho2 The Buhari-led anti-corruption crusade suffer no challenges at the interim of the administration.

\subsection{LITERATURE REVIEW}

\subsection{Conceptual Review}

\subsection{Corruption}

Corruption according to Salisu (2006 cited by Amannah 2018) is defined as "an arrangement that involves an exchange between two parties (the demander and the supplier) which:

I. Has an influence on the allocation of resources either immediately or in the future; and

II. Involves the use or abuse of public or collective responsibility for private ends".

Corruption as an act which deviates from the rules of conduct governing the action of someone in a position of public authority because of private regarding motives such as wealth, power and status. Otunuga (2016 cited by Amannah 2018) states that corruption is undoubtedly one of the greatest challenges in Nigeria. It is a challenge that is not only leading to impoverishment and loss of lives, but also threatening the stability of the country. The fight against corruption in the public sector came to limelight in 1966 when the Military identified corruption by politicians as one of the reasons for taking over the then civilian government. Since then successive governments have been waging war against the menace.

Rotimi et al (2013) see corruption to include "bribery, smuggling, fraud, illegal payments, money laundering, drug trafficking, falsification of documents and records, window dressing, false declaration, evasion, underpayment, deceit, forgery, concealment, aiding and abetting of any kind to the detriment of another person, community, society or nation". Corruption also could be youth-based among which includes cybercrime (yahoo, yahoo), thuggery, permutation, pilfering, drug peddling, paid assassins, kidnapping, prostitution, militancy, book-haram and 419 syndromes, plagiarisms among others. Otite (2000) defined corruption as a perversion of integrity or state of affairs through bribery, favour or moral depravity" ... It takes place when at least two parties have interacted to change the structure or processes of society or the behaviour of functionaries in order to produce dishonest, unfaithful or defiled situations. In other words - corruption is a systematic vice in an individual, society or a nation 


\section{International Journal of Social Sciences and Management Review}

which reflects favouritism, nepotism, tribalism, sectionalism, undue enrichment, amassing of wealth, abuse of office, power, position and derivation of undue gains and benefits.

Hoffmann and Patel (2017) say for the fact that corruption is a destructive and complex practice is openly acknowledged in Nigeria, yet it remains ubiquitous in the functioning of society and economic life. The consequences of corruption for the country and its people are, moreover, indisputable. Acts of diversion of federal and state revenue, business and investment capital, and foreign aid, as well as the personal incomes of Nigerian citizens, contribute to a hollowing out of the country's public institutions and the degradation of basic services. All the same, corruption is perhaps the least well understood of the country's challenges. Corruption tends to foster more corruption, perpetuating and entrenching social injustice in daily life. Such an environment weakens societal values of fairness, honesty, integrity and common citizenship, as the impunity of dishonest practices and abuses of power or position steadily erode citizens' sense of moral responsibility to follow the rules in the interests of wider society.

Corruption has a pervasive and troubling impact on the poor as it distorts public choices in favour of the wealthy and powerful and reduces the state's capacity to provide social safety nets. Corruption involves the improper and unlawful behaviour of public-service officials, both politicians and civil servants, whose positions create opportunities for the diversion of money and assets from the government to themselves and their accomplices. It exacerbates poverty, most especially in developing and transitional economies like Nigeria (Ekonwenrenren and Ekuobase 2015). For corruption, extortion or bribery to take place, there must be a public official with discretionary power followed by a misuse of that power. In the case of bribery, there is also collusion between the dishonest official and one or more public or private officials, and a benefit, in money or in kind, to all parties involved. This is generally practised by public officials having the direct responsibility to deliver services to the public, apply or enforce specific regulations, or levy fees or taxes.

Corruption distorts resource allocation and government performance. The causes of its development are diverse and vary from one country to country. Policies, programs and activities that are poorly conceived and managed, failing institutions, poverty, income disparities, inadequate civil servants' remuneration, and a lack of accountability and transparency are among the contributing factors. For any serious progress to be made therefore in an economy, the government must take proactive steps in the fight against corruption identified as the main cause of the crisis rocking the economy at the moment. Highly corrupt nations are always perpetuated with a vicious circle of poverty: low rate of saving which leads to low incomes and which in turn leads to low investment and productivity. The negative consequences of the prevalent corruption continue to hamper the growth and development of the economy, causes insecurity of lives and property of the citizenry as evident from several Boko Haram attacks, heightened level of poverty and unemployment.

\subsection{Types and Causes of Corruption in Nigeria}

In the introductory part of this study, Akpan and Eyo (2018) treated types of corruption as thus: supportive corruption; transactional corruption; extortive corruption; traditional and 


\section{International Journal of Social Sciences and Management Review}

modern corruption; local, national and international corruption; or representational corruption and grand and petty corruption. Konie (2003) however, summarised types of corruption, into: Vertical corruption - involves managers and decision-makers. This is more common in less developed countries; and Horizontal corruption - centres on the entire official, informed, and laymen groups in the countries. With those types of corruption mentioned above, it is permissible to focus at this point on discussing what causes the kind of corruption Nigeria is suffering from today.

What causes corruption has remained a debate within the academic circle. So far, a number of issues have been factored from the pervasive corruption in the public and private sectors of Nigeria. This ranges from leadership style, a cultural system too weak legal system of Nigeria.

On account of the weak and corrupt legal framework, Sowunmi et al (2010 cited by Rotimi et al 2013:5) opined that a weak enforcement mechanism (e.g. lack of judicial independence; weak prosecutorial institutions) is one of the major causes of corruption in Nigeria. The forces, which deter corruption, are often weak as some, if not most, of the law enforcement agencies, are themselves corrupt. In addition, rulers, politicians and civil servants are highly corrupt, and professional organizations may be incapable of sanctioning their members. Also, the literature reveals that economic situation causes corruption. Shleifer and Vishny (1993 ) and Ali and Issei (2003 cited by Rotimi et al 2013) argued that in a country where the economic condition is poor, there is a tendency for such country to experience a high level of corrupt practices which further worsen the growth rates. They also buttressed their assertion that a country with good macroeconomic performance stands to experience low (if any) level of corruption and develops rapidly. This corroborates the conclusion of Benjamin (2007 cited by Rotimi et al 2013) that hindrance to economic performance stands to economic opportunity. This corrupt practice is glaringly notice on our high and expressways where law enforcement illegally blocks the high and expressways extorting money and other valuables form road users and also causing unsolicited accident for innocent souls.

Johnston (1997) identified weak political competition as a strong factor that helps to sustain corrupt practices. He opined that this has generally played a role in sustaining most serious cases of entrenched political and bureaucratic corruption. Hence, he submitted that stronger political and economic competition could enhance accountability, open up alternatives to dealing with corrupt networks, and create incentives for political leaders to move against corruption. Unchecked awarding of white elephant projects, execution of second-best projects and worst of it is abandoned the project after a huge sum of money would have been paid to the contractors are some of the corruptions resulting from the negligence of the government.

In furthering the negligence and I-don't-care attitude of the people, Nwaobi (2004 cited by Rotimi et al 2013) posited that Nigeria must be one of the very few countries in the world where a man's source of wealth is of no concern to his neighbours, the public or the government. Wealthy people who are known to be corrupt are regularly courted and honoured by communities, religious bodies, social clubs and other private organizations. This implies that people who benefit from the largesse of these corrupt people rarely ask questions. This corruptly decorated celebrated and most times coroneted individuals further deepen and multiply the scope of corruption. Sociological and cultural factors such as 


\section{International Journal of Social Sciences and Management Review}

customs, family pressures on government officials and ethnicity also constitute a potential cause of corruption.

\subsection{Anti-Corruption Crusade}

Anti-corruption crusade designed to ensure that all Nigerians whether in private or public sector conducts themselves in an honest and ethical manner. This is to ensure a zero-tolerance approach to bribery and corruption and commitment to acting professionally, fairly and with integrity in all business dealings in line with the global best practices. Anti-corruption crusade comprises activities that oppose or inhibit corruption. This crusade different forms whose efforts vary in scope and strategy such as preventive and reactive measures drawn to stop corruption. In such framework, investigative authorities such as EFCC and ICPC and their attempts to unveil corrupt practices would be considered reactive, while education on the negative impact of corruption, or firm-internal compliance programs are classified as preventive measures.

\subsection{Growth}

Growth is a process of expanding or becoming large over a certain period. It specifically has nothing to do as far as qualitative expansion is concerned or in other words, it is a term which depicts a quantitative enlargement of a particular thing. The term growth generally carries a connotation of quantitative increase. Perhaps the most explicit statements that this connotation should be critical in interpreting the concept of economic growth are to be found in the writings of Professor Kuzneths. He argues rather forcefully that "... economic growth is essentially a quantitative concept" Kuznets 1955), and hence if we are to make substantial progress in the empirical and theoretical analysis of the growing phenomenon. "...we must consider the quantitative aspect as basic". This point is generally accepted. However, there remains widespread disagreement as to the magnitude which is in fact the relevant measure of growth. Indeed, about the only unifying element in the various quantitative" definitions of economic growth is an agreement that what ideally should be measured is the contribution of economic activity to the achievement of higher states of human welfare. In defining economic growth in this sense, it is argued that economic activity is purposive activity-that economic activity can only be identified and its results measured if there is a prior identification of the underlying purpose of that activity.

\subsection{Development}

Development is a process that creates growth, progress, positive change or the addition of physical, economic, environmental, social and demographic components. The purpose of development is a rise in the level and quality of life of the population, and the creation or expansion of local regional income and employment opportunities, without damaging the resources of the environment. Development is visible and useful, not necessarily immediately, and includes an aspect of quality change and the creation of conditions for a continuation of that change. The development could also be defined as bringing about social change that allows people to achieve their human potential. Development is a process rather than an outcome: it is dynamic in that it involves a change from one stage or condition to 


\section{International Journal of Social Sciences and Management Review}

another. Ideally, such a change is a positive one - an improvement of some sort (for instance, an improvement in maternal health).

Amartya Sen (1999) argued that "development must be judged by its impact on people, not only by changes in their income but more generally in terms of their choices, capabilities and freedoms; and the distribution of these improvements, not just the simple average for a society". The development carries a connotation of lasting change. Providing a person with bed-net for example or a water pump can often be an excellent, cost-effective way to improve her well-being, but if the improvement goes away when one-stop providing the bed net or pump, that could not normally be described as "development". Development also means an improvement in the country's economic and social conditions. Dudley Seer in his argument as to what constitutes development suggests that "while there can be value judgments on what is the development and what is not, it should be a universally acceptable aim of development to make for conditions that lead to a realisation of the potentials of human personality". In order to achieve this aim, Seer outlined several conditions such as (i) the capacity to obtain physical necessities, particularly food; (ii) a job (not necessarily paid employment) but including studying, working on a family farm or keeping house; (iii) equality, which should be considered an objective in its own right; (iv) participation in government; (v) belonging to a nation that is truly independent, both economically and politically; and (vi) adequate educational levels (especially literacy).

\subsection{Theoretical Review of Study}

The study employed a policy-oriented theory of corruption and the system theory to support the study. The policy-oriented theory was developed by Teveick, Albert and Charles in 1986, in explaining the role of government in fighting corruption. The theory opines that increase in the level of corruption in any nation either developed or developing nations will hinder the growth of the economy (Adedeji, Soyinka and Sunday 2018). Despite the fight on corruption occurrence, government involvement in corruption has seriously affected the growth of the economy negatively. Nevertheless, if corruption, whether administrative, political or financial is to be curtailed or reduced to the barest minimum, there is the need for the various subunit of government to tighten up their roles. Also, the system theory or approach was devised by David Easton in 1999 that drew heavily from the works done in biology (Adedeji, Soyinka and Sunday 2018). This theory contributed to our understanding of politics. The system theory has it that the system cannot operate effectively without the support of its sub-systems or its components units. Proper functioning of a part of the system affects the whole system, each unit of a system perform series of needed activities in any large and complex establishment these activities are usually attached to specialized units.

The theme of this theory is that, in every organization, institution, country, governmental or political set up, these are various parts or sub-systems or unit that makes up the (system) organization. These units work collectively dependent upon the effective and efficient functioning of the entire (organization) system (Adedeji, Soyinka and Sunday 2018). A part or unit of the whole system cannot function in isolation of the other parts. The functioning of a part of the system affects the whole system. Nigeria as a political system cannot operate effectively in isolation of the help or contribution of its sub-systems as supra-system; it needs the support of the sub-system to maintain a stable political system or society. Corruption in 


\section{International Journal of Social Sciences and Management Review}

any part of the system affects the whole, either political, administrative, financial corruption or otherwise. Therefore, to fight cases of fraud and corruption in this system, accounting and auditing which is a unit of the government or a sub-system of the supra-system is charged with this responsibility, if it fail in the mandated field to fight corruption, its inability or failure will increase cases of corrupt activities which will cause inefficiency to the entire system.

\subsection{Empirical Review}

A study by Rotimi and Obasaju (2013) titled "Analysis of corruption and economic growth in Nigeria" reviewed the causes and effects of corruption, without leaving out the dynamics of corruption. Also, the study looked at the relationship between corruption and the Nigerian economic growth. The researchers used the ordinary least squares (OLS) to determine the relationship between corruption and economy growth. The study applied the Granger causality method to measure the causal relationship that exists between corruption and the gross domestic product (GDP). The study revealed that corruption impairs and impacts economic growth. The researchers, therefore, recommended that Public anti-corruption initiatives and Public education campaign/programmes should be strengthened and motivated in to address the cause of corruption rather than its effects.

Another related study carried out by Enor, Chime and Ekpo (2016) titled "The Irony of Nigeria's Fight against Corruption: An Appraisal of President Muhammadu Buhari's first eight months in office" sought to appraise Nigeria's strategy in the fight against corruption under President Muhammadu Buhari's first eight months in office. The researchers used the interview and library research method in collecting data. The researchers concluded that Muhammadu Buhari envisaging the persistent escalation of corruption traits in public offices won the 2015 presidential election pools owing to his firm anti-corruption stands and inclinations to fight it to a standstill. However, he, in his first eight months just like every other Nigerian leader has failed to tackle the issue of corruption but its manifestation. The researchers, therefore, recommended that corruption can be reduced to its barest minimum if modalities are put in place to prevent and deter the manifestations of corruption rather than fight it.

Elemanya and Onya's (2016) paper entitled "analysis of President Buhari's anti-Corruption Policy: A reality or an illusion?" analysed Buhari's anti-corruption policy. The researchers found out that Buhari's fight against corruption should be holistic and transparent and recommended that the Nigerian populace and indeed the electorates that voted for a change of Buhari's government must assist the government and challenge it if need be, to fight corruption as promised, during his electioneering campaign and his inaugural speech. Another study carried out by Ugoani (2016) titled "Political will and anticorruption crusade management in Nigeria" sought to explore the relevance of political will in anticorruption crusade management in Nigeria, using exploratory research design. The researchers recommended that there should be a demonstration of credible intent by political leaders, stakeholders groups to attack perceived causes or effects of corruption at a systemic level.

In a study conducted by Sheriff Folarin in 2014 titled "Corruption, Politics and Governance in Nigeria", how corruption affects the political climate of the country was examined. The 


\section{International Journal of Social Sciences and Management Review}

study identified some of the weaknesses of the anti-corruption crusade, with the devastating effects on nation-building. The study concluded that "the dangerous consequences of corruption for the nation make it imperative that the anti-corruption war should be intense and backed by new and systematic strategies" (Folarin, 2014). The researcher recommended that "anti-corruption agencies should no longer be under the control of the executive arm of government, rather they should be independent of political corruption. Such agencies should rather be controlled and answerable to the judiciary, particularly the Supreme Court, which is often independent of the Presidency or Executive. Also, the anti-corruption agencies should be headed by a judge of the Supreme Court who has a track record of forthrightness and fearlessness (Folarin, 2014).

\subsection{METHODOLOGY/RESEARCH DESIGN}

This section explains the methodology that was used in arriving at the findings of this study. It consists of the research design, the population of study, sample and sampling procedure, and instrumentation. The chapter also contains the validity of the instrument, reliability of the instrument and procedure for data analysis.

The survey research design is adopted for this work. The survey research design is a technique of research that study, analyze and interpret existing prevailing condition. The research design enabled the researcher to administer the questionnaire to many respondents at the same time. This is in consonance with the opinion of Kerlinger (1973) that, survey design studies large and small population by selecting and studying samples drawn from the population to discover the relative incidence, distribution and inter-relation of sociological and psychological variables of the study. Therefore, the researcher has adopted this design because of its efficiency in drawing out information about the feelings and views from large subjects. Nworgu (1991) described survey research as one in which a group of people or items are studied by collecting and analyzing data from only a few people or items considered to be representative of the entire group. A survey design was used based on its power in detecting the effect of phenomena in large population there by extracting study sample responses that will best answer the questions raised by this study.

\subsection{Data Presentation and Analysis}

This part of the research consists of data presentation and analysis. The questionnaire was administered to the respondents on the subject matter. Data were collected through the responses the respondents made on the research questionnaire that was administered to them. Data presentation and analysis is based on the research problem and the objectives of the study. The analysis was done using the statistical package of social sciences (SPSS) computer software. Tables were used for clear presentation of data. The simple percentage method was also employed to analyze the data collected from the field.

The research assumed that 135 questionnaires were administered but only 123 were obtained (returned) which formed the computed analysis.

\subsection{Bio-Data of the Respondents}




\section{International Journal of Social Sciences and Management Review}

Table 4.1: Gender Distribution of the Respondents

Source: Returned Questionnaire

\begin{tabular}{lll}
\hline Gender & No. of respondents & Percentage \\
\hline Male & 63 & $51.2 \%$ \\
Female & 60 & $48.8 \%$ \\
Total & $\mathbf{1 2 3}$ & $\mathbf{1 0 0 \%}$ \\
\hline
\end{tabular}

The table above indicated gender distribution of the respondents as thus: $51.2 \%$ male and $48.8 \%$ female.

Table 4.2: Educational Qualification of the Respondents

\begin{tabular}{lll}
\hline Qualification & No. of respondents & Percentage \\
\hline SSCE & 25 & $20.3 \%$ \\
OND/NCE & 37 & $30.0 \%$ \\
HND/B.SC & 41 & $33.3 \%$ \\
Masters \& Above & 20 & $16.2 \%$ \\
Total & $\mathbf{1 2 3}$ & $\mathbf{9 9 . 8 \%}$ \\
\hline
\end{tabular}

Source: Returned Questionnaire

From the above table, $20.3 \%$ of the respondents had the minimum educational qualification of Senior Secondary Certificate Examination (SSCE), 30.0\% of the respondents hold Ordinary National Diploma (OND) or National Certificate of Education (NCE), whereas $33.3 \%$ of the respondents had either Higher National Diploma (HND) or Bachelor of Science (B.Sc) Degree, while $16.2 \%$ of the respondents were Masters Degree holders or above educational qualification.

Table 4.3: Religion of the Respondents

\begin{tabular}{lll}
\hline Religion & No. of respondents & Percentage \\
\hline African Traditional Religion (ATR) & 17 & $13.8 \%$ \\
Christianity & 71 & $57.8 \%$ \\
Islam & 35 & $28.4 \%$ \\
Total & $\mathbf{1 2 3}$ & $\mathbf{1 0 0 \%}$ \\
\hline
\end{tabular}

Source: Returned Questionnaire

The above table indicated that $13.8 \%$ of the respondents belonged to the African Traditional Religion, $57.8 \%$ of the respondents were Christians, while $28.4 \%$ of the respondents were Muslims.

Table 4.4: Occupation of the Respondents

\begin{tabular}{lll}
\hline Occupation & No. of respondents & Percentage \\
\hline Farmer & 41 & $33.3 \%$ \\
Public Servant & 44 & $35.8 \%$ \\
Student & 38 & $30.9 \%$ \\
Total & $\mathbf{1 2 3}$ & $\mathbf{1 0 0 \%}$ \\
\hline
\end{tabular}

Source: Returned Questionnaire 


\section{International Journal of Social Sciences and Management Review}

From the table above, $33.3 \%$ of the respondents were farmers, $35.8 \%$ of the respondents were public servants, while $30.9 \%$ of the respondents were students.

The Impact of Anti-Corruption Crusade on Nigerian Economy

Table 4.5: Are you satisfied with President Buhari's anti-corruption crusade?

\begin{tabular}{lll}
\hline Response & No. of respondents & Percentage \\
\hline Yes & 58 & $47.1 \%$ \\
No & 65 & $52.9 \%$ \\
Total & $\mathbf{1 2 3}$ & $\mathbf{1 0 0 \%}$ \\
\hline
\end{tabular}

Source: Returned Questionnaire

The table above shows that $47.1 \%$ of the respondents are very satisfied with the anticorruption crusade of the President Buhari-led administration, while 52.9\% of the respondents expressed great dissatisfaction in the anti-corruption campaign of the President Buhari-led administration.

Table 4.6: Has the Anti-Corruption Campaign Boost Morales of Investors in the Nigerian Market?

\begin{tabular}{lll}
\hline Response & No. of respondents & Percentage \\
\hline Yes & 52 & $42.2 \%$ \\
No & 71 & $57.8 \%$ \\
Total & $\mathbf{1 2 3}$ & $\mathbf{1 0 0 \%}$ \\
\hline
\end{tabular}

Source: Returned Questionnaire

The table above shows that President Buhari-led anti-corruption has increased the confidence of and attracted investors both local and foreign to the Nigerian market thereby boosting the economic growth and development of Nigeria by represented $42.2 \%$ affirmation, while $57.8 \%$ of the respondents state that President Buhari's anti-corruption campaign has scared investors away from the Nigerian market/economy due to lack of its sincerity.

Table 4.7: Does Whistle-blower Policy Assist the Anti-Corruption Crusade in Nigeria?

\begin{tabular}{lll}
\hline Response & No. of respondents & Percentage \\
\hline Yes & 77 & $62.6 \%$ \\
No & 46 & $37.3 \%$ \\
Total & $\mathbf{1 2 3}$ & $\mathbf{9 9 . 9 \%}$ \\
\hline
\end{tabular}

Source: Returned Questionnaire

From the above table, $62.6 \%$ of the respondents agreed that whistle-blower policy is of enormous help in the arrest, prosecution and recovery of Nigeria's stolen wealth, while $37.3 \%$ of the respondents said whistle-blower policy has little assistance to success of anticorruption crusade in Nigeria.

Table 4.8: What do you think is the major setback in the Buhari-led Anti-Corruption Crusade in Nigeria? 


\section{International Journal of Social Sciences and Management Review}

\begin{tabular}{lll}
\hline Response & No. of respondents & Percentage \\
\hline Lack of Political Will & 39 & $31.7 \%$ \\
Leadership Style & 46 & $37.3 \%$ \\
Judicial System & 38 & $30.9 \%$ \\
Total & $\mathbf{1 2 3}$ & $\mathbf{9 9 . 9 \%}$ \\
\hline
\end{tabular}

Source: Returned Questionnaire

The table above shows that the low approval rating the President Buhari-led administration is constrained by leadership (37.3\%), lack of political will (31.7\%), and the nature of Nigeria Judicial system (30.95).

\subsection{SUMMARY, CONCLUSION AND RECOMMENDATIONS}

\subsection{Summary}

Corruption is identified as a cankerworm racking havoc in the body of Nigeria's economy. Corruption depicts dishonesty or fraudulent behaviour exhibited by people in authority by giving or accepting a bribe, granting or accepting financial favours, the award of contract in the public or private sectors of the Nigerian economy which in return impede development. Corruption could be conducted in a supportive, transactional, extortive, as well as traditional or modern form. Corruption, therefore, accounts for the backwardness of Nigeria in all facets of human endeavours and has caused the deaths of well-meaning industries Nigeria ever had such as Nigeria Railway Corporation (NRC), Ajeokuta Steel Company, National Electricity and Power Authority (NEPA), Nigerian Telecommunication Company (NITEL) and so on. Even the privatisation of public enterprises was mixed with corruption. This problem has been with the country since Independence, however, the gravity of its occurrence changed over time as a result of increased greed and loss of conscience. The alarming rate of corruption in the country led to the establishments of Independent Corrupt Practices and Other Related Offences Commission (ICPC) in 2000 and the Economic and Financial Crimes Commission in 2003.

Knowing the devastation corruption brings to any economy in the world especially the developing economy, President Buhari, decried that "corruption will kill us if we do not kill corruption" with immediate alacrity. That followed by his famous quote of "I belong to everybody and I belong to nobody". This is to assure the electorates that he is answerable only to the constitution of the Federal Republic of Nigeria and the interest of the general populace instead of the usual small group of selfish powerful individuals. The leadership of President Buhari-led administration ensured full implementation of Treasury Single Account (TSA), Bank Verification Number (BVN), Integrated Personnel and Payroll Information System (IPPIS) which led to uncovering ghost workers and removing same from the government payroll, blocking leakages in government revenue and bank frauds.

\subsection{Conclusion}

Corruption, despite numerous institutions, established and policies enacted to combat it have rather fuel its spread in Nigeria. The President Buhari-led government won in the 2015 and 2019 general elections on the grounds that corruption will be eliminated to the barest minimum or to a stage where it is no longer damaging to the economic growth and 


\section{International Journal of Social Sciences and Management Review}

development. While the President Buhari-led administration has been applauded for ensuring full implementation of Treasury Single Account (TSA), Bank Verification Number (BVN), Integrated Personnel and Payroll Information System (IPPIS), Whistleblower policy and the signing of the Executive Order on the Ease of Doing Business in Nigeria; the government for its four years of administration has failed many Nigerians on a number of key issues which compromised the thrust: anti-corruption crusade. First on the list of notable mistakes that caused by the President Buhari-led anti-corruption crusade is the removal of fuel subsidy in 2016 and sudden re-appearance of same without appropriation. This is because the President himself and some of his kitchen cabinets on different occasions pronounced fuel subsidy as a conduit in siphoning public funds. Secondly, the involvement of Secretary to the Government of the Federation in the two hundred million nairas (N200,000,000.00) grass clearing contract scandal that resorts to his dismissal without prosecution.

Thirdly, the over three hundred million naira cars' contract scandal involving the Chief of Staff to the President also belittles the efforts of the President in combating corruption. Worst still, the suspect continued to occupy his position. How then did the President expect the international community to believe his commitment to the cause? Fourthly, the absorption of Mr. Maina; the alleged pension thief into federal civil service without being prosecuted hurts the image of President Buhari anti-corruption. Not to mention the National Health Insurance Scheme (NHIS) Boss, accused of misappropriating huge public funds. The fight against corruption must move away from mere pronouncement to action filled crusade where individuals found wanting must face the consequences of the law irrespective of political or ethnic affiliation.

\subsection{Recommendations}

The manifesto of President Buhari-led government hinges on the fight against corruption which he re-echoed in his famous inaugural speech where emphasised that "I belong to everybody and I belong to nobody". And for any investor or the international community to believe those words, Mr. Buhari, must match it with action. To achieve his manifesto, the President Buhari-led administration must follow the salient measures recommended here to achieve economic growth and development in Nigeria.

a. Public Declaration of Assets: There should be legislation making assets declaration public documents where each person must publish in at least two of the national dailies his/her assets declaration form. In this way, the public will cross-check with the officer's known assets to determine his sincerity or otherwise.

b. Close the disparity between civil servants and political office holders in terms of financial benefits: There is urgent need to look into the welfare of civil servants and close the gaps in wages and allowances between them and political office holders/appointees whose entitlements out-weigh the salary of civil servants.

c. There should be a constant publication of recovered loot by the corruption-fighting agencies to enhance trust and confidence in them by the public. 


\section{International Journal of Social Sciences and Management Review}

d. Appointment of individuals into sensitive public offices must be based on ones' impeccable record in order to purge dubious and criminal elements out of the public life of the Nigerian economy.

e. There should continuous auditing and publishing of financial reports of money-making institutions of government to ensure transparency and accountability.

f. The President Buhari government must step up the fight against corruption by investigating his kitchen cabinet on corruption allegation levelled against them and if found wanting must be purged from public service.

g. There should be a stiff penalty for corrupt officials and agencies colluding to defraud the government of her scarce resources.

\section{REFERENCES}

Adedeji, D. B., Soyinka, K.A. \& Sunday, O.M (2018). Corruption control in the public sector and the Nigerian accountant. International Journal of Academic Research in Accounting, Finance and Management Sciences Vol. 8, No.1, pp.91-103.

Adegoke, Niyi (2017). Corruption and sustainable development in Nigeria. Journal of Sustainable Development in Africa Vol. 19 No.1 pp48-59.

Akpan, Macaulay J.D. \& Eyo, Michael F. (2018). Anti-corruption war under President Muhammadu Buhari in Nigeria: the arsenal, casualties, victories and corruption perception appraisal. Global Journal of Politics and Law Research Vol. 6 No.3, pp.32-47.

Amannah, Peace I. (2018). Public perception of media reportage of the anti-corruption crusade of President Muhammadu Buhari. African Research Review Vol. 12 (3), No. 51, pp.8-24.

Ekonwenrenren, I \& Ekuobase, G. (2015). Curbing corruption in Nigeria using service innovation. A Multidisciplinary Journal Publication of the Faculty of Science, Adeleke University, Ede, Nigeria Vol.2, pp.103-114.

Folarin, S. (2014). Corruption, politics and governance in Nigeria. Retrieved on 4th May 2019 from http://eprints.covenantuniversity.edu.ng/3249/1/Folarin\%202.pdf.

Folarin, Sheriff (2009). The Anti-corruption war in Nigeria: A critical appraisal of the role of the ICPC and EFCC. The Nigerian Journal of Economic and Financial Crimes Vol. 1 No. 2 pp14-36.

Hoffmann, Leena K., \& Patel, Raj N. (2017). Collective action on corruption in Nigeria: A social norms approach to connecting society and institutions. Chattam House Report.

Inaugural speech by His Excellency, President Muhammadu Buhari following his swearingin as President of the Federal Republic of Nigeria on 29th May, 2015. 


\section{International Journal of Social Sciences and Management Review}

Makinde, Wasiu A. (2018). Whistle blowing policy in Nigeria: Issues and challenges. International Journal of Politics and Good Governance Vo.ix, No.9, pp.1-13.

Mutiullah, Olasupo A, \& Adekunle, Solomon B. (2017). Corruption and public governance: Implication for customer due diligence in Africa. African Research Review Vol. 11 (1) N0.45, pp88-99.

Okpala, Kenneth E., \& Enwefa, Christopher (2017). War against corruption in Nigerian public sector: An analysis of stakeholders' role. FUNAI Journal of Business and Finance Vol. 1 No.1 pp204-218.

Rotimi, Ekundayo M., et al (2013). Analysis of corruption and economic growth in Nigeria. Afro Asian Journal of Social Sciences Vol.4, No.4.2, pp.1-19.

Ugoani, John N.N (2016). Political will and anti-corruption crusade management in Nigeria. Independent Journal of Management and Production Vol.7, No.1, pp.72-97. 